\title{
Criteria for the Evaluation of Business Process Simulation Tools
}

\author{
Vesna Bosilj-Vuksic \\ and Vlatko Ceric \\ University of Zagreb, Faculty of \\ Economics and Business, \\ Zagreb, Croatia
}

vbosilj@efzg.hr vceric@efzg.hr

\author{
Vlatka Hlupic \\ University of Westminster \\ Westminster Business School, \\ London, UK
}

hlupicv@wmin.ac.uk

\begin{abstract}
This paper focuses on a process of simulation software packages selection in the context of business process change projects. The paper presents discrete event simulation, its relation to business process modelling and examples of its practical applications in business process change projects. Features of business process simulation tools are examined, the most important simulation features are identified and the criteria for their evaluation are defined. The guidelines that could help managers in the selection of business process simulation tools are proposed. The discussion addresses the limitations of the proposed guidelines. Finally, based on the conducted research and the evaluation criteria defined within the guidelines, some directions for the further improvement of business process simulation tools are given.
\end{abstract}

Keywords: Business process simulation, discrete event simulation, business process change, business process modelling tools, guidelines for the evaluation of business process simulation tools

\section{Introduction}

In a period of continuous change in global business environments, organisations, large and small, are finding it increasingly difficult to deal with, and adjust to the demands for such change. To accomplish business process change (BPC), most companies use different methods and tools which integrate components for static and dynamic modelling and measuring the performance of business processes. A majority of software tools for business process modelling have an origin in a variety of process mapping tools that provide the user with a static view of the processes being studied, but some of them are also able to show a dynamic change in business processes and

Material published as part of this publication, either on-line or in print, is copyrighted by the Informing Science Institute. Permission to make digital or paper copy of part or all of these works for personal or classroom use is granted without fee provided that the copies are not made or distributed for profit or commercial advantage AND that copies 1) bear this notice in full and 2) give the full citation on the first page. It is permissible to abstract these works so long as credit is given. To copy in all other cases or to republish or to post on a server or to redistribute to lists requires specific permission and payment of a fee. Contact Publisher@InformingScience.org to request redistribution permission. evaluate the stochastic events and random behaviour of resources. However, the results of the research in business practice showed that the data and static process modelling features were most widely used in practice, whereas the dynamic process modelling features were less frequently used (Currie \& Hlupic, 2000; Harmon, 2005). 
On the other hand, some of the frequently mentioned problems related to BPC projects include the inability to accurately predict the outcome of radical change and the inability to recognize the dynamic nature of the processes. Simulation of business processes is suggested for use in BPC projects as it allows the essence of business systems to be understood, the processes for change to be identified, process visions to be developed, new processes to be designed and prototyped and the impact of proposed changes on key performance indicators to be evaluated (Greasley \& Barlow, 1998). Obviously, simulation modelling could offer a great potential in BPC projects and the methods which combine business process modelling and simulation modelling, enabling quantitative estimations of alternative re-engineered business processes (Harmon, 2003), provide a possible approach to address the above-mentioned problem of the evaluation of alternative solutions.

The aim of this paper is to define the main simulation features of business process modelling tools. The results of the theoretical findings and the authors' experience are used to develop the guidelines that can help managers and IT experts in making a flexible and customized selection of business process tools depending on their simulation features. The criteria for business process tools evaluation are also obtained using related articles, vendors' information, software manuals and by working with some simulation packages. In summary, research approach used relates to the method of context analysis (used to analyse literature on simulation tools evaluation) as well as to empirical research (reflected in practical use of a selection of well known simulation tools for developing real-life models).

The paper is structured as follows: in the next section we discuss related work on applicability of simulation modelling in business process change projects. Then we identify, systemise and analyse simulation features of business process modelling tools. The criteria used for the evaluation of business process simulation tools are examined and discussed in the next section. The final section presents some general conclusions and directions for future work.

\section{Business Process Simulation}

Nowadays, companies are using BPM tools that incorporate support for simulation. This Section examines the causes and consequences of the gap between the decision of business process tools vendors to develop and integrate simulation features into their tools and the fact that these features are very rarely used by business practitioners.

\section{Dynamic Process Modelling Using BPM Tools}

Various methods and techniques can be used for modelling business processes in order to obtain an understanding of possible scenarios for improvement. IDEF0, IDEF3, Petri Nets, System Dynamics, Knowledge-based Techniques and Discrete-Event Simulation are some examples of widely used business process modelling techniques (Eatock, Giaglis, Paul, \& Serrano, 2000, Seila, Ceric, \& Tadikamalla, 2003). Regardless of the methods used, business process models play an important role in the different phases of BPC (Desel \& Ervin, 2000).

Notably, business process modelling is essential within BPC projects, enabling two important functions (Lin, Yang, \& Pai, 2002): (1) to capture existing processes by structurally representing their activities and related elements; and (2) to represent new processes in order to evaluate their performance. In addition to these functions, a business process modelling method should enable process evaluation and selection of alternatives. Discrete event simulation seems to be an appropriate method, and it offers a great potential in analysing business processes. According to Barber, Dewhurst, Burns, \& Rogers, (2003), the limitations of static models have been recognised by system analysts and designers for over a decade but only relatively recently simulation has been 
considered an essential component of process modelling and the term "business-process simulation" (BPS) has been coined.

The survey of the literature in this domain provides a list of reasons for the introduction of simulation modelling into process modelling. Amongst the most relevant are (Giaglis, Paul, \&

O’Keefe, 1999; Hlupic \& Robinson, 1998; Irani, Hlupic, Baldwin, \& Love, 2000; Paul, Hlupic, \& Giaglis, 1998; Pegden, Shannon, \& Sadowski, 1995; Sierhuis, Clacey, Seah, Trimble, \& Sims, 2003): simulation allows for the modelling of process dynamics and supports the creation of dynamic models of organisational processes and information systems, the influence of random variables on process development can be investigated, re-engineering effects can be anticipated in a quantitative way - quantitative process metrics that can be addressed include costs, cycle time, serviceability and resource utilisation. Furthermore, process visualisation and animation are provided, allowing multidisciplinary team members to understand the model and communicate about it and facilitating communication between clients and an analyst and simulation modelling can be increasingly used by those who have little or no simulation background or experience.

The results of surveys from business practice have shown the existence of a large potential market requiring the improvement of BPM tools with the components for dynamic modelling and measuring the performance of the processes. As a result of this, consultants and BPM software tools vendors developed simulation modelling features to support this. As noted by Hall and Harmon (2005), most modelling tools provide some form of discrete event simulation capabilities, either as part of the tool or as an available, separate add-on module.

\section{Applicability of Simulation Modelling to Business Process Change Projects}

According to Serrano and Hengst (2005), business process simulation is considered a modelling technique that is very popular amongst business process practitioners. Davies (1994), for instance, describes how some of these issues were addressed in a study of the use of simulation in a back-office process management system in the financial services sector. Giaglis and Paul (1996) suggest how simulation modelling could be used to assist in each stage of the five-step framework for the implementation of BPR proposed by Davenport (1993). The IBM PC Company in Europe used the process simulation technique to evaluate different manufacturing execution strategies and to identify the lower-cost distribution policies (Chen, 1997). Here the process simulation model was developed to define the supply chain and a strategic distribution policy was adopted based on the alternative scenarios. As a result, there was an estimated saving of approximately $\$ 40$ million per year. Giaglis, Paul, and Doukidis (1998) reported a real-life case study where discrete-event models of business processes were developed to assist two companies in realizing the expected impact of EDI on key business performance indicators. A successful deployment of BPS tools in the telecommunications industry was reported by Lee and Elcan (1996). A case study of modelling and automating business processes of a medium-sized bank introducing Internet technologies (intranet, workflow management system, Lotus Domino) was described in the paper by Nikolaidou, Anagnostopoulos, and Tsalgatidou (2001). Business process modelling was conducted using the discrete-event simulation (Petri-Nets). Hlupic and Bosilj Vuksic (2004) present a BPS model of a telephony system of a large multinational company that has been used for determining business processes that needed to be radically changed. Jaklic and Indihar Stemberger (2005) present simulation process model developed and successfully applied in a process change project at one of the Slovenian Ministries.

Though business process simulation has been promoted by consultants and software companies to be implemented in BPC projects, various authors have commented on the need to improve simulation methods for these applications (Nidumolu, Menon, N., \& Zeigler, 1998; van Eijck and de 
Vreede, 1998). Melao and Pidd (2003) conducted a survey of practitioners asking how and why BPS is used in practice. The survey revealed that users want tools that are not only easy-to-use, but also flexible enough to tackle different application areas and complex human behaviour. The survey on the use of simulation software conducted by Hlupic (2000) revealed that there are two different groups of users: academics and industrial experts. Over three-quarters of academic users and over half of industrial users use simulators. Both groups stated that the main positive features are ease of model development and visual facilities, while the main problems for industrial users were the lack of flexibility (in comparison to simulation and general purpose programming languages), the lack of links with other packages (software compatibility) and the lack of interfaces for data input. The problem is how to find a balance between these two incompatible aims. As process modelling has mostly a business rather than technical role, a modelling tool must be simple to use by a non-technical business user. However, a number of factors such as inefficient data collection, lengthy model documentation and poorly planned experimentation prevent frequent deployment of simulation models (Perera \& Liyanage, 2001). Popovic and Jaklic (2004) identified other issues concerning simulation modelling, including problem definition issues, issues regarding data collection, socio-political issues, hierarchical and modular modelling issues, granularity issues, integration issues and multi-perspective issues.

It is obvious that no single simulation package could incorporate all desirable features and selection of an appropriate package depends on the application area and the problem complexity. According to Barber et al. (2003) BPS tools are not sufficiently scalable to allow the creation of large business models. On the other hand, static modelling tools are capable of building large models of complex systems but they cannot deal with the additional complexity imposed by the temporal perspective. Therefore, an approach and procedure based on interfacing large-scale business models with selective small-scale dynamic process models is proposed.

\section{Simulation Features of Business Process Modelling Tools}

It could be very useful to produce a list of all required features for implementing DES modelling in BPC projects to help managers and IT experts in making a flexible and customised selection of these tools. However, trying to do this is rather complex for a number of reasons: the products available on the market are constantly changing; some software simulation features are better suited to particular projects than others and the simulation software selection process in organisations is typically not defined and there are often no possibilities to learn from previous experience, therefore a decision is usually based on the consultants' opinion. In order to address this problem, this Section identifies some of the most important features which should be looked at when selecting BPS software.

\section{Categories of Business Process Simulation Tools}

Two main categories of BPS software tools that may be applicable for BPC projects are: general purpose discrete event simulation (DES) tools and business process modelling (BPM) tools. DES is a field that began to develop in 1957 by the creation of the General Simulation Program (GPS) and over the history, a plethora of DES software packages and many successful applications have been reported. Nowadays, typical simulation package provides the following (Pidd \& Carvalho, 2006):

(1) Modelling tools: a graphical modelling environment, built-in simulation objects with defined properties and behaviour, sampling routines, property sheets and visual controls, 
(2) Tools to execute the simulation: a simulation executive to run a model, animated graphic, virtual reality representation and user interaction with the simulation as it runs,

(3) Tools to support experimentation: tools to define run lengths and parameters, analysis tools to enable optimisation, results interpretation and presentation and

(4) Links to other software (links to spreadsheets, databases, ERP systems).

Furthermore, issues related to how to make DES linked to other areas such as process modelling approaches were identified as simulation practice priorities by the JOS 2006 Survey (Taylor \& Robinson, 2006). A main driver for this is a general trend of enterprise integration and interoperability.

BPM tools integrate different methods to cover various aspects of the business system, such as: organisational structure of the system, internal behaviour aspects of the system, business policy and strategy, information and knowledge management. Consequently, most modelling methods and techniques integrated into BPM tools today have been developed for industrial engineering, software engineering or information systems modelling environment. Curtis, Kellner, \& Over, (1992) proposed four common perspectives in modelling business processes: functional, behavioural, organizational and informational. Based on these perspectives, Lin et al. (2002) identified a set of essential components for modelling business processes. These essential components include: activity, behaviour, resource, relation, agent, information, entity, event, verification and validation using simulation, and modelling procedure. It is obvious that these concepts should be observed and introduced in the list of simulation features' requirements.

\section{Features of DES Tools}

Many authors have described desirable software features for the selection of DES software. According to Oakshot (1997) a range of features desired from a simulation tool are: modelling flexibility, ease of use, animation, general simulation functions (e.g. warm-up period, multiple runs), statistical functions, interface with other software, product help and support, price and expandability. Pidd (1992) identified the general principles for selecting discrete simulation software by dividing these principles into three main groups. The first one is focused on computer programming, covering the field of logical machines, machine code, assembly languages, compilers and interpreters. The second group of principles analyses different simulation executive approaches, model logic, distribution sampling, random number generation and report generation. The last group of principles examines a range of factors which should be considered when appraising DES software, such as: the type of application, the expectation for end-use, knowledge, computing policy and user support.

Law and Kelton (2000) identified the following groups of features: general capabilities (e.g. modelling flexibility and ease of use), hardware and software considerations, animation, statistical capabilities (including random number generator, probability distributions, replications and warm-up period), output reports, customer support and documentation. Hlupic, Paul, \& Irani (1999) defined general criteria for the evaluation of simulation packages, which can be applied to the evaluation of any simulation package, regardless of its application area. The criteria are "naturally" classified according to their nature into 13 groups: general modelling features, visual aspects, coding aspects, efficiency, modelling assistance, testability, software compatibility, model input/output, experimentation facilities, statistical facilities, user support, financial and technical features and pedigree of the software. This study provides a list of more than 310 evaluation criteria.The evaluation framework for simulation software evaluation and simulation software selection methodology presented in the paper has been tested through several case studies. Various consulting assignments have been carried out, involving companies in manufacturing 
(Hlupic \& Paul, 1994), health (Kuljis \& Paul, 1994), oil, water treatment and other industries. All of forty simulation specialists at Accenture, based on three continents, have used this evaluation framework for software selection. The same framework has been used for teaching simulation modelling at Delft University of Technology. Furthermore, this framework formed a basis for the development of SimSelect (Hlupic \& Mann, 1995), a system for simulation software selection developed in Visual Basic 3.0. The application of the evaluation framework presented in this paper has resulted in the purchase of various simulation languages and simulators, which are have been successfully used both for education and for research at UK University.

However, it would not be realistic to expect particular BPM software to satisfy all criteria for general purpose discrete event simulation (DES) tools defined by the authors and listed above. On the other hand, the complexity of simulation and great number of simulation features and requirements acts as a constraint to the utilisation of simulation in BPC projects. Therefore, it could be useful to select the most important simulation features and to propose guidelines to be used both by managers who are looking for a suitable BPM tool to buy and by developers of BPM tools who intend to improve simulation capabilities in existing tools.

\section{Guidelines for the Simulation Software Features Evaluation}

In this paper we elaborate on the categories of simulation features as defined by Hlupic et al. (1999) in the context of business process simulation and BPC projects. The proposed framework is based on a seminal framework developed by Hlupic et al. (1999). The original framework was comprehensive, it has been widely used and it was focused on manufacturing simulators. The framework presented in this paper has adapted the original framework to the domain of business process modelling software, the original criteria were regrouped and some new criteria were added. This new framework provides the advantages of having the original generic criteria as well as new criteria specific for business process modelling software (e.g. Integration with WFM systems and BAM systems).

Four main groups of categories are defined. Features within each group are further classified into subcategories, according to their character. The main categories are:

- Hardware and software considerations: coding aspects, software compatibility, user support, financial and technical features, pedigree;

- Modelling capabilities: general features, modelling assistance;

- Simulation capabilities: visual aspects, efficiency, testability, experimentation facilities, statistical facilities;

- Input/Output issues: input and output capabilities, analysis capabilities.

Table 1 contains the evaluation criteria and classification of simulation features for the category "Hardware and software considerations". This category is divided into five subcategories, each comprising a certain number of features as described below. 
Table 1: Evaluation criteria of simulation features for the category "Hardware and software considerations"

\begin{tabular}{|c|c|c|c|c|c|}
\hline \multirow[t]{2}{*}{ CODING ASPECTS } & $\begin{array}{l}\text { Programming } \\
\text { flexibility }\end{array}$ & $\begin{array}{l}\text { Access to source } \\
\text { code }\end{array}$ & $\begin{array}{c}\text { Global } \\
\text { variables }\end{array}$ & $\begin{array}{l}\text { Built-in } \\
\text { functions }\end{array}$ & $\begin{array}{c}\text { Support of } \\
\text { programming } \\
\text { concepts }\end{array}$ \\
\hline & $\begin{array}{l}\text {-Provided } \\
\text {-Not provided }\end{array}$ & $\begin{array}{l}\text {-Possible } \\
\text {-Not possible }\end{array}$ & $\begin{array}{l}\text {-Provided } \\
\text {-Not pro- } \\
\text { vided }\end{array}$ & $\begin{array}{l}\text {-Provided } \\
\text {-Not provided }\end{array}$ & $\begin{array}{l}\text {-Provided } \\
\text {-Not provided }\end{array}$ \\
\hline \multirow[t]{2}{*}{$\begin{array}{l}\text { SOFTWARE } \\
\text { COMPATIBILITY }\end{array}$} & $\begin{array}{c}\text { Integration with } \\
\text { spreadsheet } \\
\text { packages }\end{array}$ & $\begin{array}{c}\text { Integration with } \\
\text { statistical packages }\end{array}$ & $\begin{array}{l}\text { Integration } \\
\text { with DBMS }\end{array}$ & $\begin{array}{c}\text { Integration } \\
\text { with legacy } \\
\text { applications, } \\
\text { ERP }\end{array}$ & $\begin{array}{c}\text { Integration } \\
\text { with } \\
\text { WFM systems, } \\
\text { BAM systems }\end{array}$ \\
\hline & $\begin{array}{l}\text {-Possible } \\
\text {-Not possible }\end{array}$ & $\begin{array}{l}\text {-Possible } \\
\text {-Not possible }\end{array}$ & $\begin{array}{l}\text {-Possible } \\
\text {-Not possible }\end{array}$ & $\begin{array}{l}\text {-Possible } \\
\text {-Not possible }\end{array}$ & $\begin{array}{l}\text {-Possible } \\
\text {-Not possible }\end{array}$ \\
\hline \multirow[t]{2}{*}{ USER SUPPORT } & $\begin{array}{c}\text { Documentation } \\
\text { and Tutorial }\end{array}$ & Consultancy & $\begin{array}{c}\text { Training } \\
\text { course }\end{array}$ & $\begin{array}{c}\text { Package } \\
\text { maintenance }\end{array}$ & $\begin{array}{c}\text { Demo models, } \\
\text { libraries }\end{array}$ \\
\hline & $\begin{array}{l}\text {-Provided } \\
\text {-Not provided }\end{array}$ & $\begin{array}{l}\text {-Provided } \\
\text {-Not provided }\end{array}$ & $\begin{array}{l}\text {-Provided } \\
\text {-Not } \\
\text { provided }\end{array}$ & $\begin{array}{l}\text {-Provided } \\
\text {-Not provided }\end{array}$ & $\begin{array}{l}\text {-Provided } \\
\text {-Not provided }\end{array}$ \\
\hline \multirow{2}{*}{$\begin{array}{l}\text { FINANCIAL AND } \\
\text { TECHNICAL } \\
\text { FEATURES }\end{array}$} & $\begin{array}{c}\text { Pricing and Total } \\
\text { Cost of } \\
\text { Ownership }\end{array}$ & $\begin{array}{c}\text { Frequency and } \\
\text { comprehensiveness } \\
\text { of update }\end{array}$ & Portability & & \\
\hline & $\begin{array}{l}\text {-High } \\
\text {-Medium } \\
\text {-Low }\end{array}$ & $\begin{array}{l}\text {-High } \\
\text {-Medium } \\
\text {-Low }\end{array}$ & $\begin{array}{l}\text {-Provided } \\
\text {-Not } \\
\text { provided }\end{array}$ & & \\
\hline \multirow[t]{2}{*}{ PEDIGREE } & Age & Spread & $\begin{array}{l}\text { Reputation } \\
\text { of supplier }\end{array}$ & $\begin{array}{c}\text { Availability of } \\
\text { references }\end{array}$ & \\
\hline & $\begin{array}{l}\text {-High } \\
\text {-Medium } \\
\text {-Low }\end{array}$ & $\begin{array}{l}\text {-High } \\
\text {-Medium } \\
\text {-Low }\end{array}$ & $\begin{array}{l}\text {-High } \\
\text {-Medium } \\
\text {-Low }\end{array}$ & $\begin{array}{l}\text {-High } \\
\text {-Medium } \\
\text {-Low }\end{array}$ & \\
\hline
\end{tabular}

\section{Coding aspects}

The possibility of additional coding might be very important feature of a package. This feature determines the flexibility of the software, which is especially valuable when complex systems are to be modelled. Criteria included in this group determine whether the package allows additional programming, if access to the code is possible, the programming concepts supported etc.

\section{Software compatibility}

These criteria evaluate whether the package can be interfaced to other software systems, in order to exchange data with these systems. This feature can considerably enhance the capabilities of the package, especially when complex real systems are modelled.

\section{User support}

The following criteria evaluate the type and quality of user support provided by the software supplier, which can facilitate learning and using the package. These criteria not only include technical support in the form of documentation, demo disks etc. They also include a variety of services provided by the software supplier which ease the use of the package. 


\section{Financial and technical features}

Criteria included in this group examine features of the package related to its pricing and the Total Cost of Ownership (TCO), as well as technical characteristics. Some of the issues considered here are: how expensive it is to purchase to install and maintain a certain package. TCO includes both direct and indirect costs related to the tool: the cost of purchasing the tool, plus the costs of installation, training, upgrades and support

\section{Pedigree}

These criteria refer to the origin of the package and its prominence. They also evaluate how widely the package is used, and judge the reputation of the software supplier.

The evaluation criteria of simulation features and their classification for the category "Modelling capabilities" are presented in Table 2. The aim of these criteria is to evaluate how well and precise a business process can be represented by using DES models.

Table 2: Evaluation criteria of simulation features for the category "Modelling capabilities"

\begin{tabular}{|c|c|c|c|c|c|c|}
\hline \multirow[t]{2}{*}{$\begin{array}{l}\text { GENERAL } \\
\text { FEATURES }\end{array}$} & $\begin{array}{l}\text { Experience and } \\
\text { education } \\
\text { required for } \\
\text { software use }\end{array}$ & $\begin{array}{c}\text { Ease of } \\
\text { learning }\end{array}$ & $\begin{array}{l}\text { User friend- } \\
\text { liness }\end{array}$ & $\begin{array}{l}\text { Representa- } \\
\text { tiveness of } \\
\text { models }\end{array}$ & $\begin{array}{c}\text { Formal } \\
\text { logic }\end{array}$ & $\begin{array}{c}\text { Simulation } \\
\text { modelling } \\
\text { approach } \\
\text { (process based, } \\
\text { activity based, } \\
\text { etc.) }\end{array}$ \\
\hline & $\begin{array}{l}\text {-None } \\
\text {-Some } \\
\text {-Substantial }\end{array}$ & $\begin{array}{l}\text {-Easy } \\
\text {-Not easy }\end{array}$ & $\begin{array}{l}\text {-High } \\
\text {-Medium } \\
\text {-Low }\end{array}$ & $\begin{array}{l}\text {-High } \\
\text {-Medium } \\
\text {-Low }\end{array}$ & $\begin{array}{l}\text {-High } \\
\text {-Medium } \\
\text {-Low }\end{array}$ & $\begin{array}{l}\text {-Provided } \\
\text {-Not provided }\end{array}$ \\
\hline \multirow[t]{2}{*}{$\begin{array}{l}\text { MODELLING } \\
\text { ASSISTANCE }\end{array}$} & $\begin{array}{c}\text { Documentation } \\
\text { notes }\end{array}$ & $\begin{array}{l}\text { On-line } \\
\text { help }\end{array}$ & Modularity & $\begin{array}{l}\text { Model and } \\
\text { data } \\
\text { separation }\end{array}$ & & \\
\hline & $\begin{array}{l}\text {-Provided } \\
\text {-Not provided }\end{array}$ & $\begin{array}{l}\text {-Provided } \\
\text {-Not } \\
\text { provided }\end{array}$ & $\begin{array}{l}\text {-Possible } \\
\text {-Not } \\
\text { possible }\end{array}$ & $\begin{array}{l}\text {-Possible } \\
\text {-Not possible }\end{array}$ & & \\
\hline
\end{tabular}

\section{General features}

Criteria included in this group describe general features of the package. Most of these criteria relate to modelling aspects such as the type of formal logic needed for modelling (if any), the level of model representativeness etc. There are also some criteria that evaluate the level of experience and formal education in simulation needed from the user, and examine how easy it is to learn and use the package.

\section{Modelling assistance}

Criteria systematised in this group evaluate the type and level of assistance provided by the package during modelling. For example, these criteria examine whether the package enables modular model development and writing the documentation notes (this feature enables writing a documentation concurrently with the model development), and whether the model and data can be separated.

The purpose of the simulation features is to evaluate in which way a simulation can be performed and which attributes and parameters can be used. Table 3 contains the evaluation criteria of simulation features for the category "Simulation capabilities". This category is divided into five subcategories. 
Table 3: Evaluation criteria of simulation features for the category "Simulation capabilities"

\begin{tabular}{|c|c|c|c|c|c|c|c|}
\hline \multirow[t]{2}{*}{$\begin{array}{l}\text { VISUAL } \\
\text { ASPECTS }\end{array}$} & Animation & $\begin{array}{c}\text { Type of } \\
\text { animation }\end{array}$ & $\begin{array}{c}\text { Animation } \\
\text { with visual } \\
\text { clock }\end{array}$ & $\begin{array}{l}\text { Expressive- } \\
\text { ness and } \\
\text { quality of } \\
\text { graphics }\end{array}$ & $\begin{array}{l}\text { Graphic } \\
\text { library }\end{array}$ & & \\
\hline & $\begin{array}{l}\text {-Possible } \\
\text {-Not possible }\end{array}$ & $\begin{array}{l}\text {-Full } \\
\text { animation } \\
\text {-Semi- } \\
\text { animation } \\
\text { (state-to- } \\
\text { state) }\end{array}$ & $\begin{array}{l}\text {-Provided } \\
\text {-Not } \\
\text { provided }\end{array}$ & $\begin{array}{l}\text {-High } \\
\text {-Medium } \\
\text {-Small }\end{array}$ & $\begin{array}{l}\text {-Provided } \\
\text {-Not } \\
\text { provided }\end{array}$ & & \\
\hline \multirow[t]{2}{*}{ EFFICIENCY } & Robustness & $\begin{array}{c}\text { Level of } \\
\text { detail }\end{array}$ & $\begin{array}{c}\text { Model } \\
\text { reusability }\end{array}$ & $\begin{array}{c}\text { Model } \\
\text { reliability }\end{array}$ & $\begin{array}{l}\text { Time scale } \\
\text { for model } \\
\text { building }\end{array}$ & $\begin{array}{c}\text { Model } \\
\text { chaining: } \\
\text { linking } \\
\text { outputs } \\
\text { from } \\
\text { different } \\
\text { models }\end{array}$ & $\begin{array}{l}\text { Queuing } \\
\text { policies }\end{array}$ \\
\hline & $\begin{array}{l}\text {-High } \\
\text {-Medium } \\
\text {-Low }\end{array}$ & $\begin{array}{l}\text {-High } \\
\text {-Medium } \\
\text {-Low }\end{array}$ & $\begin{array}{l}\text {-Possible } \\
\text {-Not } \\
\text { possible }\end{array}$ & $\begin{array}{l}\text {-High } \\
\text {-Medium } \\
\text {-Small }\end{array}$ & $\begin{array}{l}\text {-Large } \\
\text {-Medium } \\
\text {-Small }\end{array}$ & $\begin{array}{l}\text {-Possible } \\
\text {-Not } \\
\text { possible }\end{array}$ & $\begin{array}{l}\text {-Provided } \\
\text {-Not } \\
\text { provided }\end{array}$ \\
\hline \multirow[t]{2}{*}{$\begin{array}{l}\text { TESTABILI- } \\
\text { TY }\end{array}$} & $\begin{array}{c}\text { Logic } \\
\text { checks }\end{array}$ & $\begin{array}{c}\text { Error } \\
\text { messages }\end{array}$ & $\begin{array}{c}\text { Ease of } \\
\text { debugging }\end{array}$ & Trace files & $\begin{array}{c}\text { Step } \\
\text { function } \\
\text { (event to } \\
\text { event } \\
\text { jumping) }\end{array}$ & $\begin{array}{l}\text { Dynamic } \\
\text { display of } \\
\text { elements } \\
\text { (capacity, } \\
\text { events, } \\
\text { state) }\end{array}$ & $\begin{array}{c}\text { Display of } \\
\text { the } \\
\text { workflow } \\
\text { path }\end{array}$ \\
\hline & $\begin{array}{l}\text {-Provided } \\
\text {-Not } \\
\text { provided }\end{array}$ & $\begin{array}{l}\text {-Provided } \\
\text {-Not } \\
\text { provided }\end{array}$ & $\begin{array}{l}\text {-Easy } \\
\text {-Not easy }\end{array}$ & $\begin{array}{l}\text {-Provided } \\
\text {-Not } \\
\text { provided }\end{array}$ & $\begin{array}{l}\text {-Provided } \\
\text {-Not } \\
\text { provided }\end{array}$ & $\begin{array}{l}\text {-Possible } \\
\text {-Not } \\
\text { possible }\end{array}$ & $\begin{array}{l}\text {-Provided } \\
\text {-Not } \\
\text { provided }\end{array}$ \\
\hline \multirow[t]{2}{*}{$\begin{array}{l}\text { EXPERIMENT- } \\
\text { ATION } \\
\text { FACILITIES }\end{array}$} & $\begin{array}{c}\text { Warm-up } \\
\text { period }\end{array}$ & Breakpoints & $\begin{array}{c}\text { Speed } \\
\text { adjustment }\end{array}$ & $\begin{array}{c}\text { Automatic } \\
\text { determinati- } \\
\text { on of run } \\
\text { length }\end{array}$ & $\begin{array}{l}\text { Automatic } \\
\text { batch run }\end{array}$ & & \\
\hline & $\begin{array}{l}\text {-Provided } \\
\text {-Not } \\
\text { provided }\end{array}$ & $\begin{array}{l}\text {-Provided } \\
\text {-Not } \\
\text { provided }\end{array}$ & $\begin{array}{l}\text {-Provided } \\
\text {-Not } \\
\text { provided }\end{array}$ & $\begin{array}{l}\text {-Provided } \\
\text {-Not } \\
\text { provided }\end{array}$ & $\begin{array}{l}\text {-Possible } \\
\text {-Not } \\
\text { possible }\end{array}$ & & \\
\hline \multirow[t]{2}{*}{$\begin{array}{l}\text { STATISTICAL } \\
\text { FACILITIES }\end{array}$} & $\begin{array}{c}\text { Theoretical } \\
\text { statistical } \\
\text { distributions }\end{array}$ & $\begin{array}{c}\text { User- } \\
\text { defined } \\
\text { distributi- } \\
\text { ons }\end{array}$ & $\begin{array}{c}\text { Random } \\
\text { number } \\
\text { streams }\end{array}$ & $\begin{array}{c}\text { Output data } \\
\text { analysis }\end{array}$ & $\begin{array}{c}\text { Quality of } \\
\text { data } \\
\text { analysis } \\
\text { facility }\end{array}$ & $\begin{array}{c}\text { Distribution } \\
\text { fitting }\end{array}$ & $\begin{array}{c}\text { Confidence } \\
\text { intervals }\end{array}$ \\
\hline & $\begin{array}{l}\text {-Provided } \\
\text {-Not } \\
\text { provided }\end{array}$ & $\begin{array}{l}\text {-Possible } \\
\text {-Not } \\
\text { possible }\end{array}$ & $\begin{array}{l}\text {-Provided } \\
\text {-Not } \\
\text { provided }\end{array}$ & $\begin{array}{l}\text {-Provided } \\
\text {-Not } \\
\text { provided }\end{array}$ & $\begin{array}{l}\text {-High } \\
\text {-Medium } \\
\text {-Low }\end{array}$ & $\begin{array}{l}\text {-Provided } \\
\text {-Not } \\
\text { provided }\end{array}$ & $\begin{array}{l}\text {-Provided } \\
\text {-Not } \\
\text { provided }\end{array}$ \\
\hline
\end{tabular}

\section{Visual aspects}

Graphical presentation of simulation models and animation of simulation are very important characteristics of simulation software. Criteria included in this group concern the type and quality of graphical facilities provided by the package. These criteria evaluate, for example, whether it is possible to perform animation of simulation experiments, the types of animation provided by the package, expressiveness and quality of graphics. 


\section{Efficiency}

Efficiency is expressed both by the capability of the software to model a variety of complex systems and by the characteristics which can save time needed for modelling and improve the quality of modelling such as model reusability, reliability and time scale for model building.

\section{Testability}

This group comprises criteria that examine which facilities for model verification are provided by the package. These facilities include error messages, displays of the values of logical elements such as functions and variables, the possibility of obtaining special files for verification such as trace and echo files, provision of step function etc.

\section{Experimentation facilities}

Criteria classified in this group evaluate the variety and characteristics of experimentation facilities. These facilities are required for improving the quality of simulation results and for speeding up the process of designing experiments and of the experimentation itself.

\section{Statistical facilities}

Due to the randomness that is present in the majority of simulation models, good statistical facilities are very important. Criteria included in this group examine the range and quality of statistical facilities provided by the simulation package.

The evaluation criteria of simulation features for the category "Input/output issues" are presented in Table 4. The features are "naturally" grouped into two subcategories, according to their character.

Table 4: Evaluation criteria of simulation features for the category "Input/output issues"

\begin{tabular}{|l|l|l|l|l|}
\hline $\begin{array}{l}\text { INPUT AND } \\
\text { OUTPUT }\end{array}$ & $\begin{array}{c}\text { Input data reading } \\
\text { from files }\end{array}$ & $\begin{array}{l}\text { Quality and } \\
\text { understandability of } \\
\text { output reports }\end{array}$ & User defined output & $\begin{array}{l}\text { Periodic output of } \\
\text { simulation results }\end{array}$ \\
\cline { 2 - 5 } & $\begin{array}{l}\text {-Provided } \\
\text {-Not provided }\end{array}$ & $\begin{array}{l}\text {-High } \\
\text {-Medium } \\
\text {-Low }\end{array}$ & $\begin{array}{l}\text {-Possible } \\
\text {-Not possible }\end{array}$ & $\begin{array}{l}\text {-Provided } \\
\text {-Not provided }\end{array}$ \\
\hline \multirow{3}{*}{$\begin{array}{l}\text { ANALYSIS } \\
\text { CAPABILITIES }\end{array}$} & What-if-analysis & $\begin{array}{l}\text { Conclusion-making } \\
\text { support }\end{array}$ & \multicolumn{1}{|c|}{ Optimization } & \\
\cline { 2 - 4 } & -Provided & $\begin{array}{l}\text {-Provided } \\
\text {-Not provided }\end{array}$ & $\begin{array}{l}\text {-Provided } \\
\text {-Not provided }\end{array}$ & \\
\hline
\end{tabular}

\section{Input and output capabilities,}

Criteria included in this group investigate how the user can present the data to the package and the type and quality of output reports provided by the package. These criteria evaluate outputs' type and quality.

\section{Analysis capabilities}

Criteria systematized in this group evaluate the what-if-analysis (different scenarios comparison) and conclusion-making support which facilitates the interpretation of the simulation results, such as: the identification of trends, the slicing and dicing of data and the tracking of the cause of specific outcomes. 


\section{Discussion and Analysis}

It is apparent that a process of BPS tool selection is very complex and cumbersome. Since there are many BPS tools with various characteristics in the market, it is difficult to determine which tool is the most suitable, but the usage of proposed guidelines could make selection more efficient and successful.

\section{Limitations of the proposed guidelines}

According to the authors' opinion, criteria listed in these guidelines represent an evaluation framework that can be used for BPS tool selection by potential buyers. The majority of these criteria were derived form practical experience and survey of literature. The number of criteria proposed by Hlupic et al. (1999) was reduced from more than 310 to 70 . Even though the number is still substantial, the process of selection has been simplified because the criteria are re-classified and re-categorized. The criteria were selected according to their importance, but also based on the requirement of business practitioners and non-technical users to understand significance and functionality of the proposed features. Further reduction of the criteria could have negative impact on the quality of the guideline and the process of selection.

Some of the criteria do necessarily overlap, for example user friendliness and online help. It may be arguable therefore, as to why a specific criterion is included in one subcategory and not in another. There are also some criteria that are more general, comprising several specific criteria. For example, ease of use of the tool depends on many factors such as the quality of documentation, online help and tutorials. However, all these criteria are listed separately to emphasise their importance.

The objectives of business change projects should be taken in consideration during BPS tool selection. Therefore, different levels of importance could be assigned to features within each category and subcategory. By importance, we distinguish between crucial (high importance), desirable (medium importance), and not so important (low importance) criteria. Levels of importance are inevitable subjective and they largely depend on factors such as personal preferences, level of modelling details, objectives of simulation etc. For example, if models are to be used for modeling complex real systems, then criteria related to Modelling Flexibility, Level of Detail, Ease of Debugging or Access to Source Code would be of high importance. On the other hand, if models are to be developed for education purposes, then criteria related to User Friendliness or Ease of Learning would be most important. If project's goal is to conduct in-depth, complex, highly tuned business process simulation, then testability, statistical and experimentation facilities will be of the highest importance. If the project's scope is to give an overview of current situation or highlevel picture of business processes' performance for top-management then visual aspects and output capabilities could be the most important.

It is evident from the above discussion that BPS tools selection is a typical multi-criteria decision problem. Therefore, a method which is appropriate for making multi-objective decisions is suggested to be used based on the guideline described in Section 3.3. This method should provide a formal mechanism that can quantify the selected attributes and allow a project member to compare alternatives systematically. According to literature overview and authors' experience, the Analytical Hierarchy Process (AHP) method could be used as one of the powerful tools to help individual as well as group decision makers to convert qualitative assessment to quantitative scales. The authors plan to explore the benefits of the developed guideline through further research and the AHP method implementation. 


\section{General Evaluation of BPS Tools Features}

According to the complexity and diversity of business projects, BPS tools need to be flexible enough to cope with different application areas and different users' requirements. Consequently, BPS tools features are very different and must be evaluated for a particular tool, within a particular business project. However, some characteristics of BPS tools could be discussed in general.

The experiences from business practice showed that BPS software should be usable by people with business knowledge, but little knowledge of simulation modelling. To meet this requirement, vendors of BPS tools made them user-friendly, easy to use, flexible, and targeted at not-technical business practitioners. Because of these characteristics, BPS tools are usually less appropriate for performing complex, detailed modelling.

User support, pedigree, financial and technical features classified in the category "Hardware and software considerations" could be very different, depending on a particular BPS tool. Coding aspects like programming and access to programming code are usually not supported by BPS tools. On the other hand, software compatibility is strongly supported by developing input/output interfaces for integrating simulation engine with other software packages (databases, spreadsheets, statistical analysis packages). Modelling capabilities are also well supported, especially user friendless, ease of learning and online help. Simulation capabilities vary amongst products, but the majority of tools allow measuring and analysing time, costs, resources, throughput, capacity and bottlenecks, as well as animation. Animation enables users to watch a business process being executed step by step. Experimentation and statistical facilities are usually not supported in an adequate manner, especially in comparison with general purpose DES tools, but are most likely aligned to the level of users' knowledge about these features and their ability to use them. Output reporting and analysis capabilities vary among tools, but the majority of these tools allow easy entry of input data reading form files.

Some issues that modellers may face using BPS tool, as well as suggestions for simulation features improvement, must be pointed out. BPS tools require simulation capabilities that frequently do not exist, such as the ability to create instance profiles and user-defined instance properties, resource schedules and resource distribution among multiple concurrent processes. Some problems in handling multiple flow entities and accounting for differences among process instances have been found in practice. A mismatch between data requirement and data handling between a static and a simulation model and the lack of interface mechanisms between different modelling tools has been reported. These problems are expected to be solved by BPS tools vendors and developers. Besides, it could be useful to expand effort introducing "best practices" into BPS tools, as it was already done in a case of ERP systems. Further, BPS tools could be linked to software packages supporting pre-defined methods for in-depth analysis of data captured during simulation (such as SixSigma and Activity Based Costing). Some users have identified a need to extend the standard reporting capabilities with simulation dashboards, real-time plotting tools and graphing tools.

\section{Conclusions}

BPM tools combine formerly separated areas of business processes, IT, resource and financial modelling, enabling the companies to form a complete view of their operations and providing a framework for efficient development of robust and complete enterprise architecture. Furthermore, numerous simulation features are introduced to enable simulation models development because of the ability of simulation to investigate the reasons and consequences of change.

In this paper a framework for evaluating BPS tools is presented. A review of the existing BPS tools and their characteristics resulted in the guidelines suggested by the authors to be used in a 
process of selection of such tools. Issues related to criteria in BPS evaluation are categorised into several main groups and sub-groups. The guidelines do not enable users to select the "optimal" BPS tool, but they rather define a set of criteria which should be examined and evaluated. It is important to note that a selection of a simulation package is to a large extent a matter of personal preferences and experience, and it also depends on modelling purpose and objectives (e.g. education vs. modelling complex real systems) and as such could be rather subjective.

At present, development of the guidelines is not completed, and in order to verify and validate the proposed guidelines the authors intend to undertake a set of case studies. These case studies will provide a thorough understanding of how simulation features can be evaluated efficiently and effectively to assure projects' success and to provide better assistance to decision makers involved in a selection of simulation software tools.

\section{References}

Barber, K.D., Dewhurst, F.W., Burns, R.L.D.H. \& Rogers, J.B.B. (2003). Business-process modelling and simulation for manufacturing management. Business Process Management Journal, 9(4), 527-542.

Chen, J. (1997). Achieving maximum supply chain efficiency. IEE Solutions, June, 30-35.

Currie, W. \& Hlupic, V. (2000). Simulation modelling: The link between change management panaceas. Proceedings of the 2000 Winter Simulation Conference, 2022-2028.

Curtis, B. Kellner, M.I. \& Over, J. (1992). Process modeling. Communication of the ACM, 35(9), 75-90.

Davenport, T.H. (1993), Process innovation: Reengineering work through information technology. Cambridge, MA :Harvard Business School Press.

Davies, M.N. (1994). Back-office process management in the financial service: A simulation approach using a model generator. Journal of the Operational Research Society, 45, 1363-1373.

Desel J. \& Ervin T. (2000). Modeling, simulation and analysis of business processes. In W.M.P. van der Aalst, J. Desel, \& A. Oberweis (Eds.), Business process management: Models, techniques, and empirical studies, Vol. 1806: Lecture Notes in Computer Science (pp. 129-141). Berlin: Springer-Verlag.

Eatock, J., Giaglis, G.M., Paul, R.J., \& Serrano, A. (2000). The implications of information technology infrastructure capabilities for business process change success. In P. Henderson (Ed.), Systems engineering for business process change (pp. 127-137). London: Springer-Verlag.

Giaglis, G.M. \& Paul, R.J. (1996). It's time to engineer reengineering: Investing the potential of simulation modelling in business process redesign. In B. Sholz-Reiter \& E. Stickel (Eds.), Business process modelling (pp. 313-332). Berlin: Springer-Verlag.

Giaglis, G.M., Paul, R.J. \& Doukidis, G.I. (1998). Dynamic modelling to assess the business value of electronic-commerce. In Proceedings of the 11th International Electronic Commerce Conference, Vol. 1: Research, June, 57-73.

Giaglis, G.M., Paul, R.J. \& O'Keefe, R.M. (1999). Integrating business and network simulation models for IT investment evaluation. Logistics Information Management, 12(1/2), 108-117.

Greasley, A. \& Barlow, S. (1998). Using simulation modelling for BPR: Resource allocation in a police custody process. International Journal of Operations \& Production Management, 18(9/10), 978-988.

Hall, C., \& Harmon, P. (2005). The 2005 enterprise architecture, process modeling \& simulation tools report. Business Process Trends. Retrieved from http://www.bptrends.com

Harmon, P. (2003). Business process change: A manager's guide to improving, redesigning and automating processes. Morgan Kaufmann Publishers. 
Hlupic, V. (2000). Simulation software: An operational research society survey of academic and industrial users. In J.A. Joines, R.R. Barton, K. Kang, \& P.A. Fishwick (Eds.), Proceedings of the 2000 Winter Simulation Conference, 1676-1683.

Hlupic, V. \& Bosilj Vuksic, V. (2004). Business process modelling using SIMUL8. Proceedings of 16th European Simulation Symposium, Budapest, 191-196.

Hlupic, V. \& Mann, A. S. (1995). SimSelect: A system for simulation software selection. In C. Alexopoulos, K. Kang, W. R. Lilegdon, \& D. Goldsmith (Eds.), Proceedings of the WSC'95 - Winter Simulation Conference, Washington DC, USA, Association for Computing Machinery, New York, 720-727.

Hlupic, V. \& Paul, R.J. (1994). Simulating an automated paint shop in the electronics industry. Simulation Practice and Theory, 1(5), 195-205.

Hlupic, V., Paul, R.J. \& Irani, Z. (1999). Evaluation framework for simulation software. International Journal of Advanced Manufacturing Technology, 15, 366-382.

Hlupic, V. \& Robinson, S. (1998). Business process modelling and analysis using discrete-event simulation. In D.J. Medeiros, E.F. Watson, J.S. Carson, J.S. \& M.S. Manivannan (Eds.), Proceedings of the 1998 Winter Simulation Conference, Washington, DC, December 13-16, 1363-1369.

Irani, Z., Hlupic, V., Baldwin, L.P. \& Love, P.E.D. (2000). Re-engineering manufacturing processes through simulation modeling. Logistics Information Management, 13(1), 7-13.

Jaklic, J. \& Indihar Stemberger, M. (2005). A methodology for a business process change in public sector. Proceedings of $13^{\text {th }}$ International Conference Systems Integration 2005, Prague, 38-47.

Kuljis, J \& Paul, R.J. (1994). Organizing outpatient clinics using simulation modeling. The International Journal of Management and Systems, 10(30), 299-306.

Law, A.M. \& Kelton, W.D. (Eds.). (2000). Simulation modeling and analysis. McGraw-Hill.

Lee. Y. \& Elcan, A. (1996). Simulation modelling for process reengineering in the telecommunications industry. Interfaces, 36(3), 1-9.

Lin, F., Yang, M. \& Pai, Y. (2002). A generic structure for business process modeling. Business Process Management Journal, 8(1), 19-41.

Melao, N. \& Pidd, M. (2003). Use of business process simulation: A survey of practitioners. Journal of the Operations Research Society, 54, 2-10.

Nidumolu, S., Menon, N., \& Zeigler, B. (1998). Object-oriented business process modelling and simulation: A discrete event system specification framework. Simulation Practice and Theory, 6, 533-571.

Nikolaidou, M., Anagnostopoulos, D., \& Tsalgatidou, A. (2001). Business process modelling and automation in the banking sector: A case study. International Journal of Simulation Systems, Science \& Technology [Special Issue on Business Process Modelling], 2(2), 65-76.

Oakshott, L. (1997). Business modelling and simulation. Pitman Publishing.

Paul, R.J., Hlupic, V. \& Giaglis, G. (1998). Simulation modeling of business processes. Proceedings of the 3rd UK Academy of Information Systems Conference, Lincoln: McGraw-Hill, 311-320.

Pegden, C.D., Shannon, R.E. \& Sadowski, R.P. (1995). Introduction to simulation using SIMAN. London: McGraw-Hill.

Perera, T. \& Liyanage, K. (2001). IDEF based methodology for rapid data collection. Integrated Manufacturing Systems, 12(3), 187-194.

Pidd, M. (1992). Computer simulation in management science. John Wiley \& Sons.

Pidd, M. \& Carvalho, A. (2006). Simulation software: Not the same yesterday, today or forever. Journal of Simulation, 1, 7-20. 
Popovic A. \& Jaklic, J. (2004). Problematika simuliranja poslovnih procesov. Proceedings of DSI 2004 Management in informatika, Portoroz, 166-172.

Seila, A.F., Ceric, V. \& Tadikamalla, P. (2003). Applied simulation modeling. Southbank, Australia: Thomson Learning.

Serrano, A. \& Hengst, M. (2005). Modeling the integration of BP and IT using business process simulation. Journal or Enterprise Information Management, 18(6), 740-759.

Sierhuis, M., Clacey, W.J., Seah, C., Trimble, J.P. \& Sims, M.H. (2003). Modeling and simulation for mission operations work system design. Journal of Management Information Systems, 19(4), 85-128.

Taylor, S.J.E. \& Robinson, S. (2006). So where to next? A survey of the future for discrete-event simulation. Journal of Simulation, 1, 1-6.

Van Eijck, D. \& de Vreede, G. (1988). Simulation support for organizational coordination. Proceedings of the 31st Hawaiian International Conference on System Sciences, 633-642.

\section{Biographies}

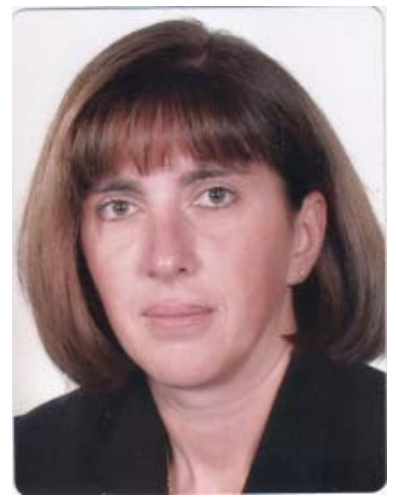

Vesna Bosilj Vuksic received a Dipl.Econ., M.Sc and Ph.D. in Information Systems from the University of Zagreb. She is a professor of Business Process Management, Simulation Modelling and Business Computing at the Faculty of Economics and Business, University of Zagreb, at the Department of Business Computing. Her current research interests are in graphical methods in simulation modelling, business process modelling and management, information systems development and e-business. She is a member of the Croatian Society for Operational Research and of the Croatian Society for Simulation Modelling (CROSSIM). She participates actively in research within the framework of the Ministry of Science and Technology's scientific projects, and is a member of international scientific research projects.

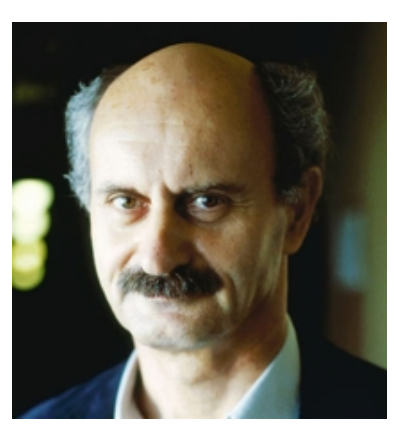

Vlatko Ceric is a Professor at the Department of Informatics at Graduate School of Business and Economics, University of Zagreb, and teaches Simulation Modelling and Expert Systems. His background is in physics, and he got his $\mathrm{PhD}$ in Organizational Science. His research is focused on business process modelling and simulation, graphic methods of simulation modelling, and decision support systems. He is the author of a number of research papers, and co-author of the book Applied Simulation Modeling published by Thomson - Brooks/Cole in 2003. He was a principal investigator of a dozen of research and professional projects, and has given a number of invited lectures in Europe and USA. He got a Fulbright grant for 1994/95. 


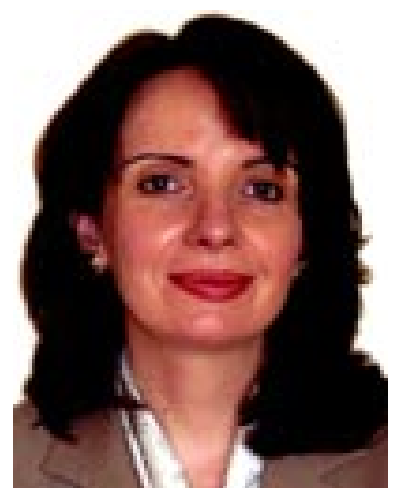

Vlatka Hlupic is a Professor and Director of the Centre for Business Information, Organisation and Process Management (BIOPoM) at Westminster Business School, University of Westminster. She received a Dipl Econ. and an MSc in Information Systems from the University of Zagreb, and a PhD in Information Systems at the London School of Economics. She has published over 150 papers in journals, books and conference proceedings and she is an associate editor, a guest editor and a member of Editorial Boards for a number of international journals. Vlatka has been acting as a consultant for a variety of manufacturing and service companies, as well as having held a variety of research and lecturing posts in England, Holland and Croatia. She has presented her work at over 50 international conferences, and has given numerous invited talks at various national and international meetings. Vlatka also acts as an expert adviser for a variety of research projects including projects sponsored by the Croatian and Thai Governments. 